\title{
A Research on Characteristic Applied-Type Talent-Cultivating Model of North China Institute of Science and Technology Gen-yin $\mathrm{CHENG}^{1,2}$,Jie-hua DING ${ }^{2,{ }^{*}}$, Jian $\mathrm{CAO}^{2}$,Jing-jing $\mathrm{TANG}^{2}$ and Shan FENG ${ }^{2}$ \\ ${ }^{1}$ Safety Training Department of North China Institute of Science and Technology, Sanhe 065201, China \\ ${ }^{2}$ College of Safety Engineering of North China Institute of Science and Technology, Sanhe 065201, China
}

Keywords: Talent-cultivating model, Application-oriented undergraduate college, Characteristic applied-type talent.

\begin{abstract}
North China Institute of Science and Technology surrounds "what kind of talents to cultivate" and "how to cultivate them", which are both essence and core of the cultivating talents, and then defines training objectives, directions and ideas through theoretical and empirical research. By optimizing the curriculum system and strengthening industry-learning-research education, NCIST builds the talent-cultivating models of application-oriented undergraduate college that is "three systems + two platforms + N modules + three levels + one development". A large number of characteristic applied-type talents have been trained to meet the needs of the development of economy and society.
\end{abstract}

\section{Introduction}

Since North China Institute of Science and Technology was promoted to undergraduate in 2002, the school made a positive exploration about characteristic development of application-oriented undergraduate and discipline construction of safety science and engineering, and proposed to explore the school-running model of characteristic development of application-oriented undergraduate. So far, the formation of talent-cultivating models with safety technical characteristics has made certain achievements and received good results.

\section{The Training Requirements for Characteristic Applied-Type Talents}

Personnel training should involve a number of factors including curriculum, educational approach, teaching methods, teaching measures, teaching organizational means and so on, of which curriculum system is the core element of talent training, and other elements of the system is in order to make the curriculum arrangements and teaching correctly and effectively, and make the training objectives implemented[1,2].

\section{Training Objectives}

In accordance with the implement teaching "Quality Project" required by the Ministry of Education, from the study and analysis of the status and role of higher education, North China Institute of Science and Technology proposes to create the talent training mode of owning the feature of Safety Technology[3] and establish a personnel training objective that is "aesthetic development including moral, intellectual and physical; coordination with knowledge, ability and quality, security-conscious, practical ability, entrepreneurial spirit, meeting the social development needs, high-quality and application-oriented"[4].The goal is also a core of safety engineering characteristic appli- 
cation-oriented talent training model.

\section{Training Orientation}

By implementing personnel training, North China Institute of Science and Technology makes graduates master universal security scientific theories and practical processing methods of applied to various industries, various organizations and the various needs of the labor market, which improves the safety and health standard of services running and production in various industries. Mine safety is regarded as the main direction of personnel training, highlighting the main features. Set the direction of industrial safety and emergency management in order to comply with the current situation of social security and demand for talents.

\section{Curriculum System}

North China Institute of Science and Technology in the research and practice of safety engineering undergraduate curriculum system, avoids the two tendencies in the construction of Safety Science and Engineering: one is to emphasize industry characteristics and ignore safety science commonality; the other is too much emphasis on safety science commonality while ignoring the specificity in their respective industries [5].

\section{The Training Methods for Characteristic Applied-type Talents}

\section{Optimizing Curriculum System}

A reasonable curriculum is a basis on enhancing innovation capability and practical ability. For example, both the formation of multiple knowledge structure and the improvement of innovation thinking ability depend on the setting of scientific theory curriculum system. Both the formation of multiple ability structure and the improvement of practical skills depend on the settings of practical teaching curriculum system. Therefore, the implementation of application-oriented training model must optimize theoretical teaching curriculum, establish and improve the practice of teaching system [6].

\section{Establishing the Teaching Course}

North China Institute of Science and Technology has 12 courses of provincial top-quality, 81 courses of university top-quality, 56 courses of bilingual teaching curriculum, 112 books of featured planning textbook.

The school insists on carrying out professional ideological education in coalfield and engaging in education related to safety engineering knowledge for all students. The creation of general education compulsory courses in a thematic taught, such as "Safe Technological Studies" and "Introduction to Mining" and so on. The elective courses are created, such as "Security Economics" and "Safe Production Scientific English" and so on. Expand training course in public PE, such as physical training, rescue training, etc. Combine with mine tough professional scholarships educate and encourage students to establish the concept of safe development, learn safety knowledge, and resolve the employment for safety-oriented production and the coal industry.

\section{Increasing the Teaching Types}

After the teaching reform, currently, teaching types include: full-time undergraduate education, the second bachelor's degree, professional degree education and adult education. School is organizing general undergraduate education, while signing coopera- 
tion agreements with Luan Group, Datong Coal Mining (Group) Co., Ltd., to carry out the second bachelor's degree and single recruit class of safety engineering, mining engineering, which trains a large number of qualified personnel needed for large state enterprises.

\section{Strengthen the Practice Ability}

The college closely carries out cooperative education with Kai Luan (Group) Co., Ltd., Shou Gang Group, China's safety production of the newspaper, and other enterprises, and built 118 practice teaching bases. Combining with security features and "Zhuo Pei" professional pilot of safety engineering approved by the Ministry of Education, the college strengthens practice, training, experiment and design practice teaching.

\section{Cooperative Education}

\section{The Practice and Design of Graduation Combined with Cooperative Education}

According to the needs of enterprises and students' ability level in their learning stage, the "3.5 +0.5 " form that three and a half semester to study in school and half-semester to practice in enterprise is used. In the seventh semester, employers and students choose each other; students work in companies and complete the graduation project in the enterprise.

\section{Encourage Undergraduates to Participate in Research Projects, Improving In- novative Capacity}

Encourage the high grade undergraduates who have already completed basic courses to participate in the research projects of teachers so as to make students bring professional theoretical knowledge in scientific practice. In recent years, nearly 10 percent of junior students participate in scientific research work of teachers; their thesis design or content of 20 percent of the graduating class are from scientific research work of teacher.

\section{Teaching as the Core, the Combination Teaching with Research}

Combining with their own research projects, teachers bring the most advanced mining technology and safety technology to the classroom so that students grasp the latest technology and dynamic field in time to stimulate student learning interest. Increasing research capacity and fruitful scientific research are rapidly integrated into the teaching practice teachers and transferred into teaching cases.

\section{Pay Attention to the Double Team Construction}

\section{Connotation and Requirements of "the Double Teacher"}

"The Double Teacher" should not only have a solid foundation of theoretical knowledge, higher education levels and certain research capacity, but also have a strong professional practice ability and a wealth of practical work experience; they should not only have generous basic theoretical knowledge and industry practical ability, but also must have the ability of integrating industry knowledge and practical ability into the education process.

\section{Training Ways of "The Double Teacher"}

The school combines with the experience of research and practical of the application-oriented undergraduate college both at home and abroad. The study of the estab- 
lishment and cultivation of "The Double Teacher" has achieved certain results. Specific methods: 1) use research projects to train teachers; 2) improve teacher quality by going out and coming in; 3) establish part-time teachers; 4) strengthen practical teaching and improve teachers' professional practical skills.

\section{The Achievements of the Characteristic Applied-type Talents}

\section{The Formation of Cultivating Models}

The determination of cultivate ideas according to orientation. Surrounding "what kind of talents to cultivate", the training standard of "moderate basis, moderate caliber, strengthen the application, enhance the ability, focus on the characteristics" is proposed. Educating people and respecting student education are regarded as a fundamental requirement for the educational work. To promote student growth and success is regarded as the starting and ending points.

\section{Building Training Mode in Accordance with the Training Objectives}

Focus on "how to train applied talents", the application-oriented training model of "three systems + two platforms + N modules + three levels +one development" was built. "Three systems" refers that the training system is divided into theoretical teaching system, practice teaching system and extracurricular quality development and innovation and entrepreneurship practice system; "two platforms" refers to set general education curriculum and basic curriculum subjects in the curriculum system; "N modules" refers to set a combination of a plurality of programs and a combination of practical teaching and to set up a number of professional courses for students to choose modules in the same majors; "three levels" refers that the practical education system is divided into the level of basic skills, the level of disciplinary skills and the level of professional technical application and comprehensive skills training; "one development" refers to encourage students to participate in extracurricular scientific research and innovation, professional skills training and social practices undertaken quality development and innovative practice system.

\section{Adhere to Individualized, Promote Personality Development}

Pay attention to students' different characteristics and personality differences, and focus on mining potential advantages of students to carry out teaching reform. Since2005, university English has implemented hierarchical teaching; advanced mathematics has set up different types of courses for students to choose; university computer basic course has taken modular teaching and assessment reform; physical education has implemented the educational reform that having a basis of "qualified + specialty" and reflecting the characteristics of safe; ideological and political theory course has implemented teaching reform of "lectures + strengthening practice"; security Zhuo Pei class has implemented CDIO model reform. Increase elective courses and expand coverage and increase innovation and quality expansion modules to meet the needs of individual development.

\section{The Formation of Cooperative Education}

\section{Cooperation in Running Schools}

Over the years, school, enterprises and other universities jointly seek and explore cooperation in running schools. Carrying out "two degrees", "single recruit class" and other academic training with Lu' an Group, Datong Coal Mining (Group) Co., Ltd. 
and other enterprises, has trained 984 students.

\section{Education Cooperation}

The cooperative companies provide practical teaching conditions and practice education base for our school and conduct research cooperation with schools preferentially to enable students to participate in research. In order to meet the business demand, the college integrates the corporate culture, philosophy and staff management technology into talent cultivation. It can enhance the corporate identity of students and can make students after graduation to adapt to the needs of enterprises work as soon as possible. Actively explore overseas cooperative education programs and keep a long-term relationship with schools and educational institutions of Indonesia, Vietnam and other countries, establishing a solid base for overseas internship.

\section{Employment Cooperation}

In China, according to the agreement of cooperative education, cooperative enterprises preferentially receive our school graduates in order that training graduate of school-enterprise cooperation can enter employment cooperation successfully; In abroad, school signed cooperative agreements of employment with many schools, such as Indonesia and other countries.

\section{Development Cooperation}

Adhere to the principle of "sincere cooperation, complementary advantages, mutual benefit and common development", achieve cooperation development among universities, enterprises and students through "cooperative running schools, educational cooperation, cooperative employment". It has formed the development model of resource sharing, full participation, mutual benefit and win-win cooperation and stimulates the vitality of own development.

\section{Conclusions}

Clearly put forward the overall objective of talent training that "security conscious, practical ability, entrepreneurial spirit and meeting the need of social development". Clearly determine training direction of mine safety mainly and jointly build the cultivating model of the application-oriented undergraduate college that "three systems + two platforms + N modules +three levels + one development".

In the process of teaching reform, clarified the differences between research cooperation and cooperative education; actively explore the personnel training ways of promotion each other of teaching and research; stick with cooperative running schools, cooperative education, cooperative employment and cooperation development with outside enterprises, which achieved better results.

On the characteristic path of development, North China Institute of Science and Technology will continue to lay a solid foundation, combine industry characteristics with subject characteristics, and accomplish the distinctive characteristics; put more emphasis on the work of the characteristic applied-type talents training and strive for cultivating more excellent talents for this industry and the society.

\section{Acknowledgements}

This research was financially supported by the Fund Project: The key projects of Hebei Province Higher Education Academy. 


\section{References}

[1] Shi-xian Zhang, Yong-ping Li. Summary to Reform of Undergraduate Applied Talents Training Mode [J].Higher Education Forum, 2010, 10(10): 6-7. (In Chinese)

[2] Shi-yue Liu. Comparison to Training Mode of Undergraduate and Tertiary Education Comparison [J]. Journal of Ningbo Institute of Technology,2005,17 (2): 66-67.(In Chinese)

[3] Wen-yao Ni. Discussion on the Safety Engineering Major Construction of North China Institute of Science and Technology [J]. China Safety Science Journal, 2004(3): 40-43. (In Chinese)

[4] Li-ming Wang. Training Pattern of Applied and Innovative Talent of Safety Engineering Major[J]. China Education Innovation Herald, 2010(1): 27-28. (In Chinese)

[5] Yong-gang Chen, Chang-chun Zhou, XinTan. Exploring Our Safety Engineering College Compound Talents Training Mode[J]. Journal of Civil Aviation Flight University of China, 2006, 17 (1): 11-13.(In Chinese)

[6] Dong-ning Lu. The Research of the Applied Talent Cultivation Mode on Undergraduate College [J]. Journal of Southwest University, 2011, 9(3):141-142. (In Chinese) 